\title{
The GSEs: Where Do We Stand?
}

\author{
William Poole
}

This article was originally presented as a speech to the Chartered Financial Analysts of St. Louis, St. Louis, Missouri, January 17, 2007.

This article first appeared in the May/June 2007 issue of Review.

Federal Reserve Bank of St. Louis Review, November/December 2013, 95(6), pp. 601-11.

$\mathbf{0}$ ne of the Federal Reserve's most important responsibilities is maintenance of financial stability. The job obviously, and sometimes dramatically, encompasses crisis response. However, the very existence of a crisis, when one occurs, often demonstrates a failure of some sort, on the part of the firms involved, the government, or the Federal Reserve. It would not be difficult to cite examples of such failures.

Not long after coming to the St. Louis Fed in 1998, I became interested in governmentsponsored enterprises, or GSEs. My interest arose when I began digging into aggregate data on the financial markets and discovered how large these firms are. The bulk of all GSE assets are in the housing GSEs-Fannie Mae, Freddie Mac, and the 12 Federal Home Loan Banks (FHLBs). Using information as of September 30, 2006-the latest available as of this writing-these 14 firms have total assets of $\$ 2.67$ trillion; given their thin capital positions, their total liabilities are only a little smaller. Just two firms -Fannie Mae and Freddie Mac-account for \$1.65 trillion of the assets, or 62 percent of all housing GSE assets. Moreover, Fannie Mae and Freddie Mac have guaranteed mortgage-backed securities outstanding of $\$ 2.82$ trillion. Thus, the housing GSE liabilities on their balance sheets and guaranteed obligations off their balance sheets are about $\$ 4.47$ trillion, which may be compared with U.S. government debt in the hands of the public of $\$ 4.83$ trillion.

In what follows, I'll confine most of my comments to Fannie Mae and Freddie Mac, where the largest issues arise. My purpose is to make the case once again that failure to reform these firms leaves in place a potential source of financial crisis. Although there is pending legislation in Congress, a major restructuring of these firms and genuine reform appear to be as distant as ever.

At the time this article was written, William Poole was the president of the Federal Reserve Bank of St. Louis. The author had thanked his colleagues at the Federal Reserve Bank of St. Louis. William R. Emmons, senior economist, provided special assistance.

This article has been reformatted since its original publication in Review: Poole, William. "The GSEs: Where Do We Stand?" Federal Reserve Bank of St. Louis Review, May/June 2007, 89(3), pp. 143-51; http://research.stlouisfed.org/publications/review/07/05/Poole.pdf.

(c) 2013, The Federal Reserve Bank of St. Louis. The views expressed in this article are those of the author(s) and do not necessarily reflect the views of the Federal Reserve System, the Board of Governors, or the regional Federal Reserve Banks. Articles may be reprinted, reproduced, published, distributed, displayed, and transmitted in their entirety if copyright notice, author name(s), and full citation are included. Abstracts, synopses, and other derivative works may be made only with prior written permission of the Federal Reserve Bank of St. Louis. 
My initial curiosity about the GSEs was stoked simply by the size of these firms. As I investigated further, I became concerned about their thin capital positions and the realization that if any of them got into financial trouble the markets and the federal government would look to the Federal Reserve to deal with the problem. As I worked through the issues, I began to speak on the subject; my first such speech was in October 2001 (Poole, 2001). I last spoke on a GSE topic two years ago, before the St. Louis Society of Financial Analysts. My title then was "GSE Risks" (Poole, 2005). Given that the risks did not seem likely to disappear any time soon, about six months ago I settled on a GSE topic once again.

Today I want to look back over the past few years to summarize a few of the changes that have occurred at the GSEs and in the regulatory environment they face. It is no exaggeration to say these have been event-filled years for the GSEs, primarily because of disclosures of accounting irregularities at Fannie Mae and Freddie Mac. Although these firms stopped growing when the irregularities were disclosed, I will emphasize that once they get their houses in good order they will likely resume rapid growth because of the special advantages they enjoy in the marketplace from their ties to the federal government. I remain hopeful that Congress will eventually pass meaningful GSE reform legislation. Private sector financial firms ought to have an intense interest in reform legislation. Still, given that there seems to be so little appreciation of the importance of the GSE issue, where do they-and we-go from here?

Before proceeding, I want to emphasize that the views I express here are mine and do not necessarily reflect official positions of the Federal Reserve System. I thank my colleagues at the Federal Reserve Bank of St. Louis for their comments-especially Bill Emmons, senior economist, who provided special assistance.

\section{THE HOUSING GSEs SINCE JUNE 9, 2003}

Although the housing GSEs are less obscure than they used to be, they are not much discussed in recent months. A year ago I would have noted that it was not unusual to find stories about the GSEs on the front pages of major financial newspapers. They were the subject of substantial debate in Congress and among financial policy experts. They had escaped from obscurity, primarily because of publicity in recent years over their accounting irregularities. But today they seem to be returning to obscurity.

For Fannie Mae and Freddie Mac, the two stockholder-owned housing GSEs, history can be divided into two distinct eras-before June 2003 and after. June 9, 2003, was the day the board of directors of Freddie Mac announced discovery of significant accounting irregularities. The stock prices of both Freddie Mac and Fannie Mae plunged, as investors immediately realized that something might have gone terribly wrong with both GSEs. Subsequent investigations by private experts and public authorities confirmed the fears of many investors and financial supervisors. These giant, fast-growing firms had poor accounting systems and financial controls.

Because it is important for my analysis later, keep in mind these facts: First, the effect of disclosure of accounting irregularities at Freddie Mac on June 9, 2003, led to a decline of 16 percent in Freddie's stock price and 5 percent in Fannie's stock price that day. However, as I'll document later, the effect of these disclosures on the mortgage market was negligible. Similarly, when Fannie's 
accounting irregularities were disclosed on September 22, 2004, its stock fell by 6.5 percent that day and by a total of 13.5 percent over a three-day period; the mortgage rate was again unaffected.

Fortunately for financial stability, the accounting irregularities at Freddie Mac had been designed, as we later learned, to understate earnings by a total of about $\$ 9$ billion over a period of years. Thus, there was no question of Freddie Mac defaulting on any of its obligations and immediately unleashing unpredictable effects on its counterparties or the financial system. In 2004, we learned that Fannie Mae's accounting was revealed to be faulty. In December 2006, Fannie restated its earnings for 2002, 2003, and the first half of 2004, revealing that it had overstated its earnings by a total of about $\$ 6$ billion.

Fannie and Freddie are supervised by the Office of Federal Housing Enterprise Oversight, or OFHEO. In both cases, OFHEO's early response to disclosure of the accounting irregularities was to declare the enterprises "significantly undercapitalized" because their extremely high leverage makes uncertainty of any kind about the true capital backing of their portfolios a risk to their own safety and soundness, as well as the stability of the financial system. Beginning in the first quarter of 2004, OFHEO required Freddie Mac to hold capital at least 30 percent above the statutory minimum level; OFHEO imposed the identical requirement on Fannie Mae in the third quarter of 2005. In addition, OFHEO required the firms to correct their accounting; undertake a thorough review of corporate governance, incentives, and compensation; appoint an independent chief risk officer; and refrain from increasing their retained portfolios.

The stunning accounting irregularities at Freddie Mac and Fannie Mae served as wake-up calls both to the GSEs themselves and to the supervisory and legislative communities. Freddie Mac fired virtually all of its top-level management immediately in June 2003 and then, a few months later, fired the new CEO it had hired to replace the original disgraced CEO. $\stackrel{1}{ }$ Barely a year-and-a-half later, Fannie Mae ejected its own top managers, who had repeatedly declared that, unlike Freddie's, its own books were clean. The boards of both companies agreed to a series of governance reforms designed to bring the GSEs into line with other large financial firms. Hundreds of millions of shareholder dollars were committed to rebuilding accounting and control systems at both firms. Both firms agreed to restate earnings for the past few years; so massive was this undertaking that neither firm is current on its financial reporting. Freddie did release its annual report for 2005 but, according to its press release of January 5, 2007, may revise its results materially for the first nine months and the third quarter of 2006. Nor is Fannie filing current reports. In December 2006, Fannie filed its Form 10-K for 2004 with the Securities and Exchange Commission (SEC). Currently, investors in common stock or debt obligations issued by both companies rely on partial and incomplete information subject to material revision.

The GSE accounting scandals constituted a rude awakening for OFHEO and Congress. OFHEO was caught napping at Freddie Mac but, to its credit, then identified Fannie Mae's shortcomings on its own. Once alerted to the problems, OFHEO's tenacious investigations into wrongdoing at both Freddie Mac and Fannie Mae spurred investigations by the SEC and the Department of Justice. Congressional hearings were held, and GSE reform legislation was passed in oversight committees of both houses of Congress in 2004 and 2005, although no final legislation has been enacted as of this time. I'll have more to say about reform legislation later, because I think this is an important missing piece of the overall puzzle. 
Meanwhile, the FHLBs - the "other housing GSEs"-were enduring accounting and control crises of their own. Two of the twelve FHLBs signed written regulatory agreements in 2004 with their supervisor, the Federal Housing Finance Board (FHFB), to rectify portfolio risk-management deficiencies. Then, in 2005, 10 of the 12 FHLBs failed to meet their agreed deadline to register their stock with the SEC. Like Fannie Mae and Freddie Mac, all of the FHLBs restated their earnings for recent years; all have now returned to timely filing of accounting statements.

So where do we stand? I would characterize the current situation as a period of uneasy waiting. The GSEs have grown much more slowly, and they have been more reticent in public in recent quarters than they had been during the pre-2003 decade. It appears that they want to pursue a low-key strategy while memories of their accounting and control failures gradually fade. Their aim, apparently, is to return to the environment before heightened scrutiny arose in 2003.

\section{WHAT HAS BEEN ACCOMPLISHED: ANALYSIS OF GSE RISKS}

Although I think much more needs to be done, it would be a mistake to believe that nothing useful was done after severe accounting problems surfaced in June 2003. In general terms, the most important achievement is a much broader and better-informed discussion of the risks to financial stability posed by the GSEs. 2 We were fortunate that the GSE accounting and governance scandals did not threaten the immediate solvency of the enterprises and that the problems surfaced when the economy and financial markets were strong.

I will point to six major contributions to the public investigation into, and debate about, the risks posed by the GSEs. There have been other contributors, to be sure, but this list provides what I think is a good overview of the issues and what we have learned so far:

- a 2003 study by Dwight Jaffee of interest rate risks run by the GSEs;

- a 2003 study by OFHEO of the potential systemic risks posed by the GSEs;

- a series of testimonies and speeches by Federal Reserve Board Chairman Alan Greenspan;

- a series of research papers prepared by Federal Reserve System staff members;

- the results of a Federal Reserve ad hoc study group investigating counterparty exposures and risks in the over-the-counter interest rate derivatives markets;

- and an economic-capital analysis of Fannie Mae and Freddie Mac prepared by Kenneth Posner, an equity analyst at Morgan Stanley.

These bullet points provide the flavor of some of the recent work on the GSEs. The appendix to this speech provides a brief summary of each of these items and citations.

Considering these results as a whole, we have learned a great deal in recent years about the way the GSEs operate, the risks they are taking and how they attempt to manage them, and what effects the GSEs have on financial markets during normal times as well as during periods of market turbulence. Armed with this knowledge, lawmakers and policymakers are in a much better position to make needed improvements in the statutory and regulatory environment in which the GSEs operate. 


\section{THE CASE FOR FUNDAMENTAL REFORM}

I continue to believe that the nation would be well-served by turning the GSEs into genuinely private firms, without government backing, implied or explicit. If they bolster their capital, they can function perfectly well as purely private firms.

A key issue for many is whether privatizing Fannie and Freddie would raise mortgage rates paid by borrowers. We now have some solid evidence on how the mortgage market would function if the housing GSEs became fully private firms. A careful econometric investigation by three economists at the Board of Governors last year (Lehnert, Passmore, and Sherlund, 2006, abstract) reached this conclusion: "We find that GSE portfolio purchases have no significant effects on either primary or secondary mortgage rate spreads." Put another way, the 30-year mortgage rate fluctuates in tandem with the rate on 10-year Treasury bonds and the spread over the Treasury rate is not affected by portfolio purchases by Fannie and Freddie.

Another approach to acquiring evidence on the effects on the mortgage rate of mortgage purchases by Fannie and Freddie is to examine what happened when their portfolios stopped growing in the wake of disclosures of accounting irregularities. Those disclosures led OFHEO to impose 30 percent temporary surcharges on the firms' required minimum capital levels. Freddie Mac's capital surcharge was imposed in January 2004, whereas Fannie Mae's capital surcharge became effective in September 2004. $\underline{3}$ To meet the higher capital ratio, the two firms had to do some combination of raising new capital and reducing their portfolios.

The retained portfolios of mortgages and mortgage-backed securities (MBS) held by Fannie and Freddie grew strongly in the years preceding the OFHEO orders. For example, if we look at year-end figures for 2002 and 2003, we see that over the course of 2003 the two firms' retained portfolios grew by a net of 12.3 percent and, at the end of 2003 , they held 22 percent of outstanding mortgages on 1- to 4 -family properties. Net growth of their retained portfolios then stopped; over the course of both 2004 and 2005, their total portfolios of mortgages and MBS fell slightly. In 2006, their retained portfolios continued to decline and by the end of the third quarter their portfolios were below year-end 2005. Meanwhile, the total market continued to expand. The combined market share of Fannie and Freddie fell from 22 percent at the end of 2003 to 14 percent at the end of the third quarter of 2006.

What happened to the mortgage spread when the GSEs stopped accumulating ever-larger portfolios? Nothing. Because fixed-rate mortgages are subject to prepayment risk, whereas the 10-year Treasury bond is not, there is a degree of variability of the mortgage spread. But if the cessation of the GSEs' portfolio growth had made a difference, it surely would have shown up in the data. The annual average of the spread in 2003, before the OFHEO orders that restricted Fannie and Freddie's portfolio growth, was 180 basis points; the spread was 157 basis points in both 2004 and 2005.

Nor did we observe any sort of shock to the market when the accounting irregularities at Freddie were disclosed in June 2003. The spread was 196 basis points in May 2003, 198 basis points in June, and 196 basis points in July. Consider also January 2004, when OFHEO imposed a capital surcharge on Freddie. That month, the mortgage spread was 159 basis points. The month before, the spread was 161 basis points; the month after, 156 basis points. The OFHEO order 
applying to Fannie came in September 2004. That month the spread was 163 basis points; the month before, 159; the month after, 162 .

Toward the beginning of my remarks, I noted that disclosure of the accounting irregularities did affect the stock prices of the two firms. Now we see that there was no effect on the mortgage market. The issue, clearly, is the profitability of the firms and not effects on the mortgage market. The effects of problems at Fannie and Freddie on the mortgage market have been minimal because the market contains many competent and well-capitalized competitors that can readily pick up the slack when other players stumble.

Financial firms throughout the economy ought to have an intense interest in reforming the GSEs. One reason is simply that banks and other financial firms, and many nonfinancial firms, hold large amounts of GSE obligations and GSE-guaranteed MBS. I believe that many risk managers simply accept that GSEs are effectively backstopped by the Federal Reserve and the federal government without ever thinking through how such implicit guarantees would actually work in a crisis. The view seems to be that someone, somehow, would do what is necessary in a crisis. Good risk management requires that the "someone" be identified and the "somehow" be specified. I have emphasized before that if you are thinking about the Federal Reserve as the "someone," you should understand that the Fed can provide liquidity support but not capital. ${ }^{4}$ As for the "somehow," I urge you to be sure you understand the extent of the president's powers to provide emergency aid, the likely speed of congressional action, and the possibility that political disputes would slow resolution of the situation.

There is a long-run issue that goes beyond that of today's systemic risk. The fact is that it is very profitable for a firm to be able to borrow at close to the Treasury rate, lend at the market rate, and hold little capital. That is why the promise of constraints on the portfolio growth at Fannie and Freddie had a significant effect on their stock prices. Any firm with such a privileged position will want to extend its scope of operations. Over the past 15 years, Fannie Mae and Freddie Mac have grown much more rapidly than has the stock of mortgages outstanding and, as a consequence, now hold or guarantee a large fraction of U.S. home mortgages. At the end of 1990, they held in their portfolios 5 percent of the mortgages for 1 - to 4 -family properties; the share peaked at 22 percent at the end of 2003; and, at the end of the third quarter of 2006, the share was 14 percent. Given the powerful incentive Fannie and Freddie have to grow, the systemic risk they pose to the economy will also grow.

Once their current accounting problems are fully resolved, Fannie and Freddie will want to resume their growth. It is simply very profitable to be able to borrow at close to the Treasury rate and invest in mortgages while holding minimal capital. Banks maintain capital ratios double or more the ratios that Fannie and Freddie maintain. Banks pay deposit insurance premiums to the Federal Deposit Insurance Corporation, whereas Fannie and Freddie pay no insurance premiums. Assuming that the implied guarantee would, in a crisis, lead to a federal bailout, U.S. taxpayers bear the risk while the shareholders and managers of Fannie and Freddie enjoy the profits. This situation encourages these firms to grow vigorously.

These two firms, however, cannot meet their growth targets in the long run if they confine their operations to conforming home mortgages. Their interest in increasing the conforming mortgage limit is clear. Moreover, in my opinion, it is inevitable that they will look for ways to 
extend their operations into new areas. They have that clear incentive because of the implicit federal guarantee they enjoy. For them to extend their operations into market segments already well served by existing private firms will not enhance the efficiency of mortgage markets or reduce costs to mortgage borrowers.

There are two possible ways to constrain the operations of the GSEs to areas with a clear public purpose. One is to end the implied federal guarantee so that Fannie Mae and Freddie Mac compete on an equal basis with other fully private firms. The other is to place restrictions on the size of their owned portfolios if they retain their privileged position. Their owned portfolios should be limited to mortgages held temporarily in the process of securitization.

Absent complete privatization, or on the way to it, Congress should strengthen the powers of OFHEO or a successor regulator. OFHEO has weaker powers than provided by law to the federal bank regulators - the Office of the Comptroller of the Currency, the Federal Reserve, and the Federal Deposit Insurance Corporation. The GSE supervisory framework remains fragmented and weak, as the GAO [Government Accountability Office] has pointed out on numerous occasions. .5 Thus, structural change of the GSEs and their supervision should be at the top of the reform agenda. There is a glaring need for legislation to clarify the bankruptcy process should a GSE fail. At present, there is no process and no one knows what would happen if a GSE becomes unable to meet its obligations.

Freddie Mac and Fannie Mae both got into trouble with accounting irregularities in part because of the complexities under generally accepted accounting principles for derivatives positions and rules determining which assets should be reported at market value and which should be reported at amortized historical cost. Sound risk management practices require that GSE management base decisions on market values, or estimates as close to market values as financial theory and practice permit. The reason is simple: Fannie Mae and Freddie Mac pursue policies that inherently expose the firms to an extreme asset/liability duration mismatch. They hold longterm mortgages and MBS financed by short-term liabilities. Given this strategy, they must engage in extensive operations in derivatives markets to create synthetically a duration match on the two sides of the balance sheet. These operations expose the firm to a huge amount of risk unless the positions are measured at market value.

Almost all the assets and liabilities of the GSEs are either traded actively in excellent markets or have values that can be accurately measured by prices in such markets. For this reason, the financial condition of the GSEs ought to be measured through fair-value accounting and such accounts ought to be the principal yardstick of condition and performance.

\section{CONCLUSIONS}

Since the GSE accounting scandals emerged in mid-2003, one thing has remained rock-solid: The GSEs have continued to borrow at yields only slightly higher than those of the U.S. government and noticeably lower than those available to any other AAA-rated private company or entity. In other words, despite the vast recent accumulation of knowledge about the significant risks run by the GSEs, as well as their inability (or unwillingness) to manage these risks, investors 
in GSE debt securities appear unmoved. Upon reflection, the lack of market discipline evident during this crisis period is striking - like a dog that did not bark. This fact indicates to me that there still is a significant problem with the GSEs that needs to be fixed.

The obvious answer to why the dog did not bark is that the so-called implicit guaranteethat is, the belief by investors that the U.S. government would not allow the GSEs to default on their debt obligations-has not been removed. Indeed, the talk of increased GSE regulation and the failure of structural-reform legislation to become law may actually have reinforced the belief of many that, overall, the government is perfectly happy with the situation as it is. The GSEs remain politically powerful, if less strident than they were a few years ago.

Three essential reforms are needed to eliminate the GSEs' threat to financial stability. First is a limit on their portfolio growth, second is an increase in their minimal required capital, and third is satisfactory bankruptcy legislation so that, should the worst happen, federal authorities can deal with the problem in an orderly way.

Freddie Mac apparently does not expect any significant increases in constraints on its operations. Funds that could have been used to build capital to better protect taxpayers have instead been used to increase common stock dividends. Freddie set a quarterly dividend of $\$ 0.22$ in the fourth quarter of 2002 and has increased the dividend every year since. As of the fourth quarter of 2006, the dividend stands at $\$ 0.50$ per quarter, more than twice its level four years earlier.

Fannie Mae cut its dividend in half in early 2005 to build capital, but I'll hazard a guess that once it starts issuing regular financial statements the company will increase its dividend rather than build capital further.

I began this speech noting that the Federal Reserve has a responsibility to maintain financial stability. That responsibility includes increasing awareness of threats to stability and formation of recommendations for structural reform. I do not believe that a GSE crisis is imminent. However, for those who believe that a GSE crisis is unthinkable in the future, I suggest a course in economic history. 


\section{APPENDIX}

\section{Summaries of Recent Studies on GSE Issues}

Jaffee (2003) Study of GSE Interest Rate Risk

Dwight Jaffee was one of the first to "peer through" the public disclosures provided by the GSEs about the interest rate risks they incurred and how they managed them. Jaffee concluded that the GSEs actually incurred significant interest rate and liquidity risks, despite their own characterization of such risks as being minimal. Subsequent events and analysis have proven Jaffee correct.

\section{OFHEO (2003) Study of Potential Systemic Risks Posed by GSEs}

Even before the GSE accounting scandals broke, the GSEs' safety-and-soundness supervisor had prepared a study comprising scenarios in which the GSEs might contribute to systemic risk. Although OFHEO concluded that the likelihood of one or both GSEs contributing to financialsystem instability was very small, the agency recommended to Congress that its (OFHEO's) supervisory powers should be enhanced to further safeguard the GSEs and the financial system.

\section{Public Statements by Chairman Alan Greenspan (2005a,b,c)}

Federal Reserve Chairman Greenspan (2005a) rejected the idea of stronger GSE regulation in favor of portfolio limits, stating that,

World-class regulation, by itself, may not be sufficient and, indeed, might even worsen the potential for systemic risk if market participants inferred from such regulation that the government would be more likely to back GSE debt in the event of financial stress...We at the Federal Reserve believe this dilemma would be resolved by placing limits on the GSEs' portfolios of assets.

Chairman Greenspan also drew attention to the strains the GSEs could place on the over-thecounter interest rate derivatives markets due to their portfolio-hedging activities.

\section{Research Papers by Federal Reserve Staff $\underline{6}$}

One of these papers estimated the pass-through by Fannie Mae and Freddie Mac of their fundingcost advantage into primary mortgage rates, finding a mere 7 basis points of pass-through. Another paper provided evidence against the GSEs' claims that their purchasing behavior stabilizes mortgage rates during periods of market turbulence. Other papers discuss (i) likely competitive interactions between the GSEs and large banks that will be subject to Basel II capital regulation and (ii) the ill-structured incentives the GSEs face to increase the size of their portfolios.

\section{Ad Hoc Federal Reserve Study Group Examining GSE Impacts on Interest Rate Derivatives Markets (Board of Governors, 2005)}

The study group identified potential channels through which disruptions at the GSEs could flow through to other market participants in the over-the-counter markets for interest rate derivatives, like swaps, interest rate options, and swaptions (options on swaps). The study group reported that market participants felt current risk-management practices were sufficient to contain risks posed by the GSEs. 


\section{Economic-Capital Analysis of GSEs by Morgan Stanley (Posner, 2005)}

Kenneth Posner, an equity analyst at Morgan Stanley, isolated the distinct economic risks faced by the GSEs and estimated how much capital the firms would need to provide adequate protection to debtholders to justify an AA senior-unsecured bond rating. This analysis assumed that there would be no support forthcoming (or expected by financial-market participants) from the federal government. His estimate of the required equity-to-assets capital ratio was in the range of 4 to 7 percent, about twice as high as the current GSE ratios of closer to 3 percent. Thus, the GSEs would be significantly undercapitalized today if there were no expectation of government support of their liabilities.

\section{NOTES}

1 Freddie Mac's board of directors had misjudged at first how deeply ingrained the internal-control and governance problems were and had hired the former CFO to become the new CEO.

$\underline{2}$ For a more detailed discussion of this topic, see Poole (2005).

$\underline{3}$ See http://www.ofheo.gov/media/pdf/capclass93004.pdf.

4 For a discussion of Federal Reserve emergency powers, see Poole (2004).

5 Most recently, the GAO criticized GSE oversight in Walker (2005).

6 These include Passmore (2005), Passmore, Sherlund, and Burgess (2005), Lehnert, Passmore, and Sherlund (2006), Hancock et al. (2005), Frame and White (2005), and Emmons and Sierra (2004).

\section{REFERENCES}

Board of Governors of the Federal Reserve System (Parkinson, Patrick and Gibson, Michael) and Federal Reserve Bank of New York (Mosser, Patricia; Walter, Stefan and LaTorre, Alex). "Concentration and Risk in the OTC Markets for U.S. Dollar Interest Rate Options," March 2005; http://www.federalreserve.gov/BoardDocs/Surveys/OpStudySum/OptionsStudySummary.pdf.

Emmons, William R. and Sierra, Gregory E. "Incentives Askew? Executive Compensation at Fannie Mae and Freddie Mac." Regulation, Winter 2004, 27(4), pp. 22-28.

Frame, W. Scott and White, Lawrence J. "Fussing and Fuming over Fannie and Freddie: How Much Smoke, How Much Fire?" Journal of Economic Perspectives, Spring 2005, 19(2), pp. 159-84.

Greenspan, Alan. "Regulatory Reform of the Government-Sponsored Enterprises." Testimony before the Committee on Banking, Housing, and Urban Affairs, U.S. Senate, April 6, 2005a; http://www.federalreserve.gov/boarddocs/testimony/2005/20050406/default.htm.

Greenspan, Alan. "Risk Transfer and Financial Stability." Speech at the 41st Annual Conference on Bank Structure and Competition, Federal Reserve Bank of Chicago, May 5, 2005b; http://www.federalreserve.gov/boarddocs/speeches/2005/20050505/default.htm.

Greenspan, Alan. Monetary Policy Report to the Congress. Question and answer session after testimony before the Committee on Financial Services, U.S. House of Representatives, July 20, 2005c.

Hancock, Diana; Lehnert, Andreas; Passmore, Wayne and Sherlund, Shane M. "An Analysis of the Potential Competitive Impacts of Basel II Capital Standards on U.S. Mortgage Rates and Mortgage Market Securitization." Basel II White Paper No. 4, Board of Governors of the Federal Reserve System, April 2005. 
Jaffee, Dwight. "The Interest Rate Risk of Fannie Mae and Freddie Mac." Journal of Financial Services Research, August 2003, 24(1), pp. 5-29.

Lehnert, Andreas; Passmore, Wayne and Sherlund, Shane M. "GSEs, Mortgage Rates, and Secondary Market Activities." Finance and Economics Discussion Series Working Paper 2006-30, Divisions of Research and Statistics and Monetary Affairs, Board of Governors of the Federal Reserve System, September 2006; http://www.federalreserve.gov/pubs/ feds/2006/200630/200630pap.pdf; forthcoming in Journal of Real Estate, Finance and Economics.

Office of Federal Housing Enterprise Oversight. "Systemic Risk: Fannie Mae, Freddie Mac, and the Role of OFHEO." Report to Congress, February 2003; http://www.fha.gov/webfiles/1145/sysrisk.pdf.

Passmore, Wayne. "The GSE Implicit Subsidy and the Value of Government Ambiguity." Real Estate Economics, Fall 2005, 33(3), pp. 465-83.

Passmore, Wayne; Sherlund, Shane M. and Burgess, Gillian. "The Effect of Housing Government-Sponsored Enterprises on Mortgage Rates." Real Estate Economics, Fall 2005, 33(3), pp. 427-63; http://www.federalreserve.gov/pubs/feds/2005/200506/200506pap.pdf.

Poole, William. "The Role of Government in U.S. Capital Markets." Presented before the Institute of Governmental Affairs, University of California at Davis, October 18, 2001; http://fraser.stlouisfed.org/docs/historical/frbsl_history/presidents/poole/20011018.pdf.

Poole, William. Remarks presented to the panel on government-sponsored enterprises, 40th Annual Conference on Bank Structure and Competition, Federal Reserve Bank of Chicago, May 6, 2004; http://fraser.stlouisfed.org/docs/historical/frbsl_history/presidents/poole/20040506.pdf.

Poole, William. "GSE Risks." Federal Reserve Bank of St. Louis Review, March/April 2005, 87(2, Part 1), pp. 85-92; http://research.stlouisfed.org/publications/review/05/03/part1/Poole.pdf.

Posner, Kenneth. "Fannie Mae, Freddie Mac, and the Road to Redemption." Morgan Stanley Equity Research, July 2005.

Walker, David M. "Housing Government-Sponsored Enterprises: A New Oversight Structure Is Needed.”Testimony before the Committee on Banking, Housing, and Urban Affairs, U.S. Senate, April 21, 2005; http://www.gao.gov/new.items/d05576t.pdf. 
